Clim. Past, 8, 391-402, 2012

www.clim-past.net/8/391/2012/

doi:10.5194/cp-8-391-2012

(c) Author(s) 2012. CC Attribution 3.0 License.

\title{
Holocene evolution of the Southern Hemisphere westerly winds in transient simulations with global climate models
}

\author{
V. Varma ${ }^{1}$, M. Prange ${ }^{1,2}$, U. Merkel ${ }^{1}$, T. Kleinen ${ }^{3}$, G. Lohmann ${ }^{4}$, M. Pfeiffer ${ }^{4}$, H. Renssen ${ }^{5}$, A. Wagner ${ }^{2,4}$, S. Wagner ${ }^{6}$, \\ and M. Schulz ${ }^{1,2}$ \\ ${ }^{1}$ MARUM - Center for Marine Environmental Sciences, University of Bremen, 28334 Bremen, Germany \\ ${ }^{2}$ Faculty of Geosciences, University of Bremen, 28334 Bremen, Germany \\ ${ }^{3}$ Max Planck Institute for Meteorology, 20146 Hamburg, Germany \\ ${ }^{4}$ Alfred Wegener Institute for Polar and Marine Research, 27568 Bremerhaven, Germany \\ ${ }^{5}$ Department of Earth Sciences, Faculty of Earth and Life Sciences, VU University Amsterdam, \\ 1081HV Amsterdam, The Netherlands \\ ${ }^{6}$ HZG Centre for Materials and Coastal Research, 21502 Geesthacht, Germany
}

Correspondence to: V. Varma (vvarma@ marum.de)

Received: 23 May 2011 - Published in Clim. Past Discuss.: 30 May 2011

Revised: 25 January 2012 - Accepted: 25 January 2012 - Published: 5 March 2012

\begin{abstract}
The Southern Hemisphere Westerly Winds (SWW) have been suggested to exert a critical influence on global climate through the wind-driven upwelling of deep water in the Southern Ocean and the potentially resulting atmospheric $\mathrm{CO}_{2}$ variations. The investigation of the temporal and spatial evolution of the SWW along with forcings and feedbacks remains a significant challenge in climate research. In this study, the evolution of the SWW under orbital forcing from the mid-Holocene (7 kyr BP) to pre-industrial modern times $(250 \mathrm{yr} \mathrm{BP})$ is examined with transient experiments using the comprehensive coupled global climate model CCSM3. In addition, a model inter-comparison is carried out using orbitally forced Holocene transient simulations from four other coupled global climate models. Analyses and comparison of the model results suggest that the annual and seasonal mean SWW were subject to an overall strengthening and poleward shifting trend during the course of the midto-late Holocene under the influence of orbital forcing, except for the austral spring season, where the SWW exhibited an opposite trend of shifting towards the equator.
\end{abstract}

\section{Introduction}

Mid-latitude westerly winds belong to the prominent features of the global tropospheric circulation. The present-day positions of the Southern Hemisphere Westerly Winds (SWW) during austral summer (December-January-February) and winter (June-July-August) are illustrated in Fig. 1. The SWW dominate climate dynamics and influence the precipitation patterns between $\sim 30^{\circ} \mathrm{S}$ and $70^{\circ} \mathrm{S}$ (e.g. Thresher, 2002; Shulmeister et al., 2004). Changes in strength and position of the SWW may affect the large-scale Atlantic hydrography and circulation through the impact on the IndianAtlantic Ocean water exchange by Agulhas leakage (Sijp and England, 2009; Biastoch et al., 2009). Furthermore, it has been suggested that the SWW exert a crucial influence on the global ocean circulation through wind-driven upwelling of deep water in the Southern Ocean (Toggweiler and Samuels, 1995; Kuhlbrodt et al., 2007; Sijp and England, 2009). The potentially resulting influence on atmospheric $\mathrm{CO}_{2}$ variations on orbital timescales has been controversially discussed (Toggweiler et al., 2006; Menviel et al., 2008; Tschumi et al., 2008; Anderson et al., 2009; Moreno et al., 2010; d'Orgeville et al., 2010). Therefore, understanding the variability and the impact of various forcings on the SWW remains a significant area of investigation. 

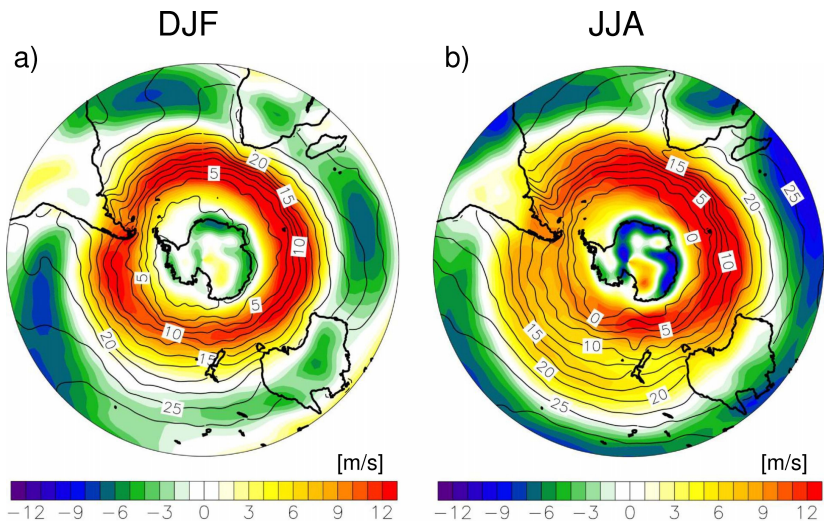

Fig. 1. Present-day Southern Hemisphere zonal wind climatology at $850 \mathrm{hPa}$ for (a) austral summer (DJF) and (b) austral winter (JJA), based on NCEP/NCAR reanalysis data (1968-1996; Kalnay et al., 1996). Overlaid isotherms (contours) represent the climatological sea surface temperatures $\left({ }^{\circ} \mathrm{C}\right)$ for the corresponding seasons based on the NODC World Ocean Atlas (Levitus et al., 1998). During DJF, the northern margin of the zonal wind shows a more southward confined pattern, while during JJA, it extends further to the north. In general, the surface westerly winds cover the region between $\sim 30^{\circ} \mathrm{S}$ and $70^{\circ} \mathrm{S}$, with the present-day strongest wind centred at around $\sim 50^{\circ} \mathrm{S}$.

The variability of the SWW on glacial-interglacial timescales has been discussed in some earlier works, in which contradicting results regarding the direction of the meridional shift of the mean wind were presented. While some climate modelling studies suggested a poleward shift in storm tracks and SWW during the Last Glacial Maximum (Valdes, 2000; Wyroll et al., 2000; Kitoh et al., 2001; Shin et al., 2003), other models simulated an equatorward (Kim et al., 2003) or no latitudinal displacement, but rather an intensification (Otto-Bliesner et al., 2006) of the mean westerlies. Likewise, proxy-based reconstructions of the glacial SWW provided contradictory views with claims of a poleward displacement (e.g. Markgraf, 1987; Markgraf et al., 1992) in contrast to evidence of an equatorward shift (e.g. Heusser, 1989; Lamy et al., 1998, 1999; Shulmeister et al., 2004) compared to pre-industrial conditions. Lamy et al. (2010) suggested that past variations in the SWW were not only characterized by latitudinal shifts but also by expansions and contractions of the wind belt. For the deglacial peak warmth in Antarctica ( $\sim 12-9 \mathrm{kyr}$ ago), they provided evidence for a minimal latitudinal extent of the belt, analogous to its present-day summer configuration.

An important forcing of global climate on longer time scales is accomplished by changes in the seasonal insolation caused by the varying Earth orbital parameters. This astronomical forcing is generally regarded as a dominant factor for glacial-interglacial climate changes (Milankovitch, 1941; Hays et al., 1976; Berger, 1978; Imbrie et al., 1992). Although the climate of the Holocene is generally considered as relatively stable compared to the last glacial (e.g. Grootes

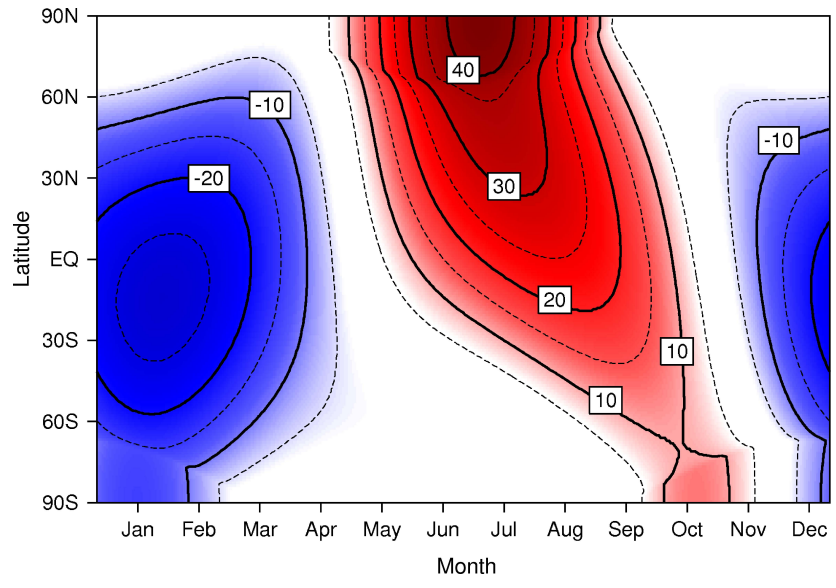

Fig. 2. Latitudinal distribution of insolation in $\mathrm{W} \mathrm{m}^{-2}$ at the top-of-the-atmosphere for $7 \mathrm{kyr}$ BP minus present-day, calculated according to Berger (1978), through the year.

and Stuiver, 1997), it has also been suggested that there have been long-term trends in the spatial and temporal patterns of surface temperature during the Holocene (e.g. Battarbee and Binney, 2008). A considerable variation in the seasonal and latitudinal distribution of insolation, especially a decrease in austral winter-spring insolation accompanied by an increase in austral summer-fall insolation, can be observed between $7 \mathrm{kyr}$ BP and present-day (Fig. 2). These changes in seasonal insolation might have caused long-term variations in the structure, position, and intensity of the SWW on multimillennial timescales (e.g. Markgraf et al., 1992; Lamy et al., 2001, 2010; Jenny et al., 2003). The aim of this study is to analyze the response of the SWW to the changes in insolation during the mid-to-late Holocene using transient experiments with the comprehensive global climate model CCSM3. In addition, we compare this simulated Holocene evolution of the SWW under orbital forcing with transient experiments from a range of other global climate models. These analyses will lead us to the suggestion that the annual and seasonal mean SWW experienced a poleward shifting trend in general - except for the austral spring season - during the course of the Holocene under orbital forcing, consistently in all climate models used for this inter-comparison.

\section{Methods}

\subsection{Experimental setup for CCSM3}

To study the Holocene evolution of SWW under the influence of orbital forcing, transient experiments have been carried out using the comprehensive global climate model CCSM3 (Community Climate System Model version 3). NCAR's (National Center for Atmospheric Research) CCSM3 is a state-of-the-art fully coupled model, composed of four separate components representing atmosphere, ocean, land and 
sea-ice (Collins et al., 2006). Here, we employ the lowresolution version described in detail by Yeager et al. (2006). In this version the resolution of the atmospheric component is given by $\mathrm{T} 31$ ( $3.75^{\circ}$ transform grid), with 26 layers in the vertical, while the ocean has a nominal resolution of $3^{\circ}$ (like the sea-ice component) with refined meridional resolution $\left(0.9^{\circ}\right)$ around the equator and a vertical resolution of 25 levels.

From a pre-industrial equilibrium simulation (Merkel et al., 2010), the model was integrated for $400 \mathrm{yr}$ with conditions representing $9 \mathrm{kyr}$ BP orbital forcing to reach a new quasi-equilibrium. After this spin-up, transient experiments were carried out by applying an acceleration (by a factor of 10) to the orbital forcing year until present-day. The underlying assumptions for the application of this acceleration technique are that orbital forcing operates on much longer timescales (>millennia) than those inherent in the atmosphere and surface mixed layer of the ocean (months to years), and that climate changes related to long-term variability of the thermohaline circulation during the time period considered are negligible in comparison with orbitallydriven surface temperature variations (Lorenz and Lohmann, 2004; Lorenz et al., 2006). Climate trends of the last $9000 \mathrm{yr}$, imposed by the external orbitally driven insolation changes, are represented in the experiments with only 900 simulation years with the application of acceleration by a factor of 10. Thus, it was possible to conduct three Holocene transient experiments with different initial conditions within the available computer resources. While the first transient run was initialized with the quasi-equilibrated $9 \mathrm{kyr} \mathrm{BP}$ state, the second and third transient runs used the 8.9 and $8.8 \mathrm{kyr}$ BP climates from the first transient run as initial conditions at $9 \mathrm{kyr}$ BP. Throughout the Holocene experiments, greenhouse gas concentrations as well as aerosol and ozone distributions were kept at pre-industrial values as prescribed by the protocol of the Paleoclimate Modelling Intercomparison Project (PMIP), Phase II (Braconnot et al., 2007). Besides, variations in the Sun's output of energy and changes in continental ice-sheets were ignored such that variations in the orbital parameters were the sole external forcing in the model simulations.

\subsection{Model inter-comparison}

In addition to our CCSM3 experiments, results from five other Holocene transient climate model simulations are analyzed here in order to study the evolution of the SWW under insolation changes. These models are ECHO-G (Lorenz and Lohmann, 2004; Wagner et al., 2007), COSMOS (Sect. 2.2.3), ECBilt-CLIO-VECODE (Renssen et al., 2009) and CLIMBER2-LPJ (Kleinen et al., 2010). As in the CCSM3 transient runs, all these models have been forced by orbital variations only, keeping greenhouse gas concentrations constant at their pre-industrial levels. A short and very general overview of these simulations is given below and detailed descriptions are available from the given references.

\subsubsection{ECHO-G (I)}

Holocene climate has been simulated using the coupled atmosphere-ocean general circulation model ECHO-G (Legutke and Voss, 1999). The atmospheric part of this model is the fourth generation of the European Centre atmospheric model of Hamburg (ECHAM4, Roeckner et al., 1996). The prognostic variables are calculated in the spectral domain with a triangular truncation at wave number 30 (T30), which corresponds to a Gaussian longitude-latitude grid of approximately $3.8^{\circ}$. The vertical domain is represented by 19 levels. The ocean model includes a dynamicthermodynamic sea-ice model and is defined on a grid with approximately $2.8^{\circ}$ resolution (with increased meridional resolution of $0.5^{\circ}$ in the tropics to allow a more realistic representation of the ENSO phenomenon) and 20 irregularly spaced levels in the vertical. Acceleration by a factor of 10 has been applied to the orbital forcing in these experiments to produce a two-member ensemble of transient Holocene runs covering the last $7000 \mathrm{yr}$ (Lorenz and Lohmann, 2004).

\subsubsection{ECHO-G (II)}

Model and forcing are identical to ECHO-G (I), except for the fact that there is no acceleration applied on the orbital forcing for the Holocene transient run (Wagner et al., 2007). Comparing the results of the non-accelerated ECHO-G (II) experiment with those from the accelerated ECHO-G (I) allows an assessment of the effect of orbital acceleration on the Holocene simulation of the SWW.

\subsubsection{COSMOS}

The core of COSMOS consists of the atmosphere model ECHAM5 (Roeckner et al., 2003) and the ocean model MPIOM (Marsland et al., 2003). For long-term integrations, a low- resolution version of this model is applied with spectral $\mathrm{T} 31$ (3.75 ${ }^{\circ}$ transform grid) resolution in the atmosphere and approximately $3^{\circ}$ horizontal resolution in the ocean. In the vertical, atmosphere and ocean model grids are defined on 19 and 40 levels, respectively. The ocean model includes a dynamic-thermodynamic sea-ice model with viscous-plastic rheology. A dynamic vegetation module is coupled to the land surface model JSBACH allowing an interactive adaptation of the terrestrial biosphere to varying climate conditions (Brovkin et al., 2009). Orbital acceleration with a factor of 10 has been applied to simulate the past $8000 \mathrm{yr}$.

Besides the simulations with coupled general circulation models described above, two Holocene runs with Earth system Models of Intermediate Complexity (EMICs) are also included in this study, they being, ECBilt-CLIO-VECODE and CLIMBER2-LPJ. 
Table 1. Brief summary of the climate models used for inter-comparison.

\begin{tabular}{|c|c|c|}
\hline Model name & Orbital acceleration & Resolution \\
\hline CCSM3 & by a factor of $10 ; 3$ member ensemble & $\begin{array}{l}\text { T31 - Atmosphere \& Land: } 3.75^{\circ} ; 26 \text { layers } \\
\text { Ocean \& Ice: } 3.6^{\circ} \times 1.6^{\circ} ; 25 \text { layers }\end{array}$ \\
\hline ECHO-G (I) & by a factor of $10 ; 2$ member ensemble & $\begin{array}{l}\text { T30 - Atmosphere \& Land: } 3.8^{\circ} ; 19 \text { layers } \\
\text { Ocean \& Ice: } 2.8^{\circ} ; 20 \text { layers }\end{array}$ \\
\hline ECHO-G (II) & non-accelerated; 1 simulation & $\begin{array}{l}\text { T30 - Atmosphere \& Land: } 3.8^{\circ} ; 19 \text { layers } \\
\text { Ocean \& Ice: } 2.8^{\circ} ; 20 \text { layers }\end{array}$ \\
\hline COSMOS & by a factor of $10 ; 1$ simulation & $\begin{array}{l}\text { T31 - Atmosphere \& Land: } 3.75^{\circ} ; 19 \text { layers } \\
\text { Ocean \& Ice: } 3^{\circ} ; 40 \text { layers }\end{array}$ \\
\hline ECBilt-CLIO-VECODE & non-accelerated; 1 simulation & $\begin{array}{l}\text { T21 - Atmosphere: } 5.6^{\circ} ; 3 \text { layers } \\
\text { Ocean: } 3^{\circ} ; 20 \text { layers }\end{array}$ \\
\hline CLIMBER2-LPJ & non-accelerated; 1 simulation & $\begin{array}{l}\text { Atmosphere: } 51^{\circ} \times 10^{\circ} \\
\text { Ocean: zonally averaged, with } 2.5^{\circ} \text { latitudinal } \\
\text { resolution; } 11 \text { layers }\end{array}$ \\
\hline
\end{tabular}

a)

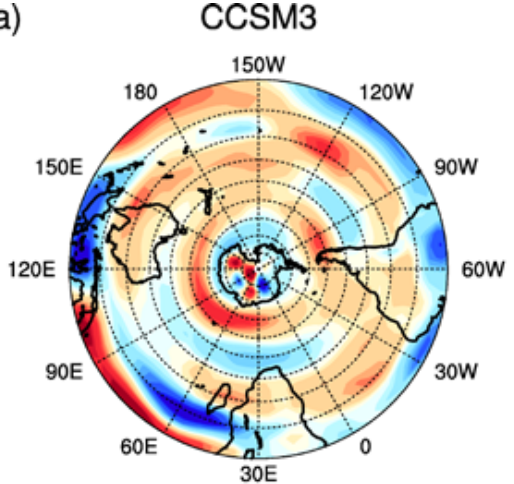

d)

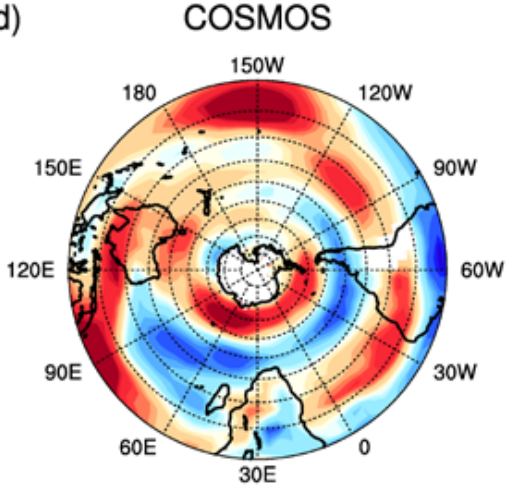

b)

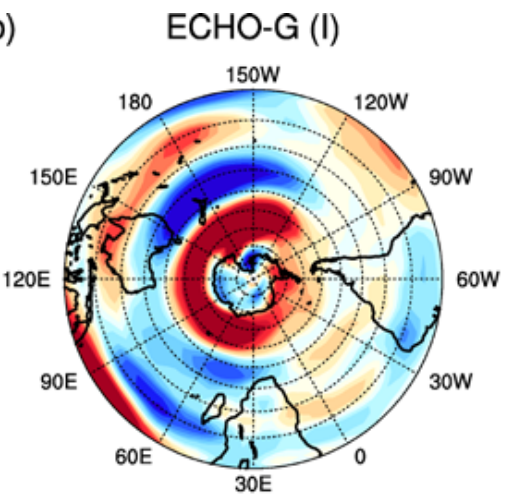

e) ECBilt-CLIO-VECODE

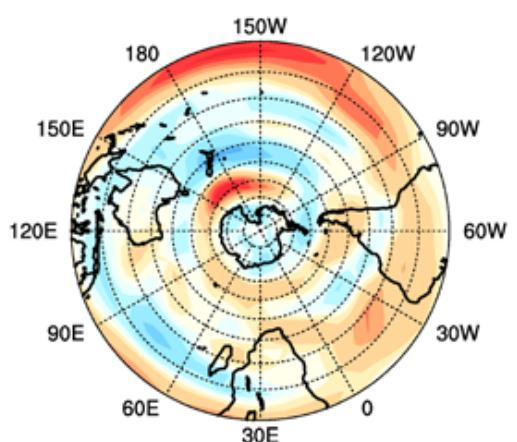

c)

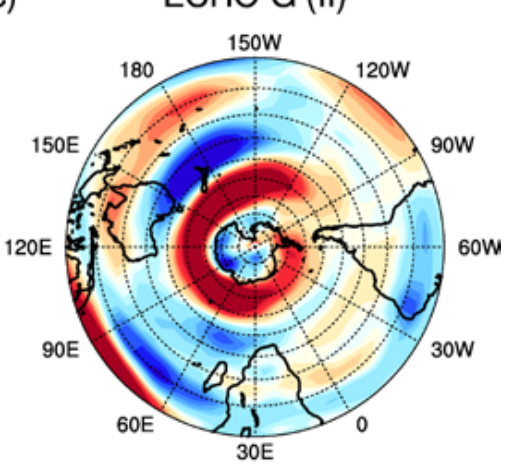

f)

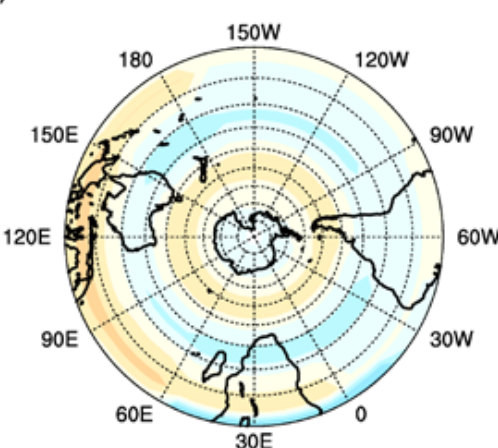

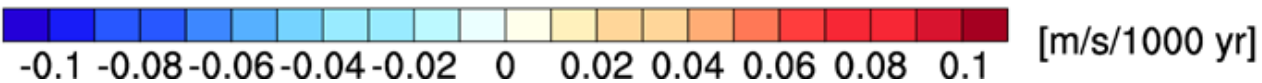

Fig. 3. Trend in the annual-mean low-level zonal wind in (a) CCSM3, (b) ECHO-G (I), (c) ECHO-G (II), (d) COSMOS, (e) ECBilt-CLIOVECODE, and (f) CLIMBER2-LPJ for the period $7 \mathrm{kyr}$ BP to $250 \mathrm{yr}$ BP. All polar stereographic plots represent the Southern Hemisphere, with latitudes placed at $10^{\circ}$ intervals, starting from the equator to $90^{\circ} \mathrm{S}$. 


\subsubsection{ECBilt-CLIO-VECODE}

The first EMIC transient run was carried out with version 3 of ECBilt-CLIO-VECODE. The atmospheric component is ECBilt, a quasi-geostrophic model with 3 layers in the vertical and T21 $\left(\sim 5.6^{\circ}\right)$ horizontal resolution (Opsteegh et al., 1998). CLIO is the oceanic component and consists of a freesurface, primitive-equation ocean general circulation model coupled to a dynamic-thermodynamic sea-ice model (Goosse and Fichefet, 1999). CLIO is defined on 20 levels in the vertical and has a $3^{\circ}$ horizontal resolution. VECODE interactively simulates the dynamics of trees and grasses (Brovkin et al., 2002). Orbital forcing without acceleration was applied to simulate the past $9000 \mathrm{yr}$.

\subsubsection{CLIMBER2-LPJ}

The second EMIC used in this inter-comparison is CLIMBER2-LPJ (Petoukhov et al., 2000). This model consists of a 2.5-dimensional statistical-dynamical atmosphere with a resolution of approximately $51^{\circ}$ (longitude) by $10^{\circ}$ (latitude), a zonally averaged ocean resolving three basins with a latitudinal resolution of $2.5^{\circ}$, and a sea-ice model. CLIMBER2-LPJ also contains dynamic vegetation, oceanic biogeochemistry, a model for marine biota, and a sediment model (Archer, 1996; Brovkin et al., 2002, 2007). The transient simulations were carried out with non-accelerated orbital forcing for the past $8000 \mathrm{yr}$, keeping greenhouse gas forcing fixed as in the other model experiments to pre-industrial levels.

The model descriptions are summarized in Table 1 . The spatial distribution of the annual-mean SWW averaged over the period $7 \mathrm{kyr} \mathrm{BP}$ to $250 \mathrm{yr} \mathrm{BP}$ represented in various models is given in Fig. 1 of the Supplement.

\section{Results}

In this section, we present the simulated insolation-forced SWW Holocene trends for all climate models used for the inter-comparison. As the strength and position of the SWW are strongly related to sea-surface temperature (Brayshaw et al., 2008; Lu et al., 2010; Chen et al., 2010), we will also analyse the modelled trends in surface temperature. In order to have a time period of comparison which is common for all model simulations, all analyses have been done for the period $7 \mathrm{kyr}$ BP to $250 \mathrm{yr}$ BP. For CCSM3 and ECHO-G (I) we have used the three-member and two-member ensemble means, respectively.

\subsection{Annual and seasonal mean trends in SWW}

The spatial distribution of Holocene trends in the annualmean low-level zonal wind in the Southern Hemisphere for the period $7 \mathrm{kyr}$ BP to $250 \mathrm{yr}$ BP for all models is represented in Fig. 3. The zonal wind trends are plotted at $850 \mathrm{hPa}$ for
CCSM3, ECHO-G (I and II) and COSMOS, and at the lowermost model level for ECBilt-CLIO-VECODE $(800 \mathrm{hPa})$ and CLIMBER2-LPJ. All models exhibit a general trend of strengthening in the southern and central SWW region and a weakening trend in the northern part of the SWW belt, which can be interpreted as a poleward displacement of the annual-mean westerly circulation during the course of the mid-to-late Holocene (Fig. 3). This spatio-temporal wind pattern resembles a long-term trend of the Southern Annular Mode (or Antarctic Oscillation) towards its positive phase (e.g. Thompson and Wallace, 2000; Sen Gupta and England, 2006). Strengthening of the SWW in the latitudinal belt between about $40^{\circ} \mathrm{S}$ and $60^{\circ} \mathrm{S}$ (i.e. the SWW core region) is most intense and continuous in ECHO-G (I and II), followed by CCSM3. While COSMOS shows a pronounced strengthening of the SWW in the region between $\sim 50^{\circ} \mathrm{S}$ and $70^{\circ} \mathrm{S}$, ECBilt-CLIO-VECODE simulates a less annular pattern, but, with respect to the zonal mean, a strengthening in the core SWW latitude belt is seen. CLIMBER2-LPJ produces the weakest trends, probably due to its simplified dynamics that does not explicitly simulate eddy momentum transports.

The simulated temporal evolution of the annual-mean SWW in all models used for inter-comparison is represented by an index and is displayed in Fig. 4. The index is defined as the difference of the zonally averaged zonal low-level winds between the latitudes $55^{\circ} \mathrm{S}$ and $35^{\circ} \mathrm{S}$ and is a measure for latitudinal displacements of the SWW belt (Varma et al., 2011). An evident trend observed in all the models is the strengthening of the low-level winds towards $55^{\circ} \mathrm{S}$ during the course of the Holocene (Fig. 4). The strongest changes occur during the mid-Holocene (4000 to $6000 \mathrm{yr} \mathrm{BP}$ ) in almost all the models. Again, ECHO-G (I) and ECHO-G (II) are very similar, CLIMBER2-LPJ follows the deterministic insolation, CCSM3 and COSMOS show pronounced internal variability for the last $3000 \mathrm{yr}$.

The zonally averaged simulated Holocene trends in lowlevel zonal winds separately for each season are represented in Fig. 5 (see Figs. 2-5 of the Supplement for the maps of seasonal trends in Southern Hemisphere zonal winds). For the March-April-May (MAM) season, all models show the most pronounced southward shift and strengthening of SWW in the latitudinal belt between about $40^{\circ} \mathrm{S}$ and $60^{\circ} \mathrm{S}$. During the June-July-August (JJA) season, CCSM3, ECHO-G (I and II) and CLIMBER2-LPJ sustain the pattern of SWW strengthening in that latitudinal belt, whereas ECBilt-CLIOVECODE exhibits a weakening in this region. The most striking feature in Fig. 5 is the SWW behaviour during the September-October-November (SON) season. This season shows the trend of a SWW weakening (between the latitudes $\sim 40^{\circ} \mathrm{S}$ and $60^{\circ} \mathrm{S}$ ) and a northward shift in all the models, i.e. opposite to the annual-mean trend. 

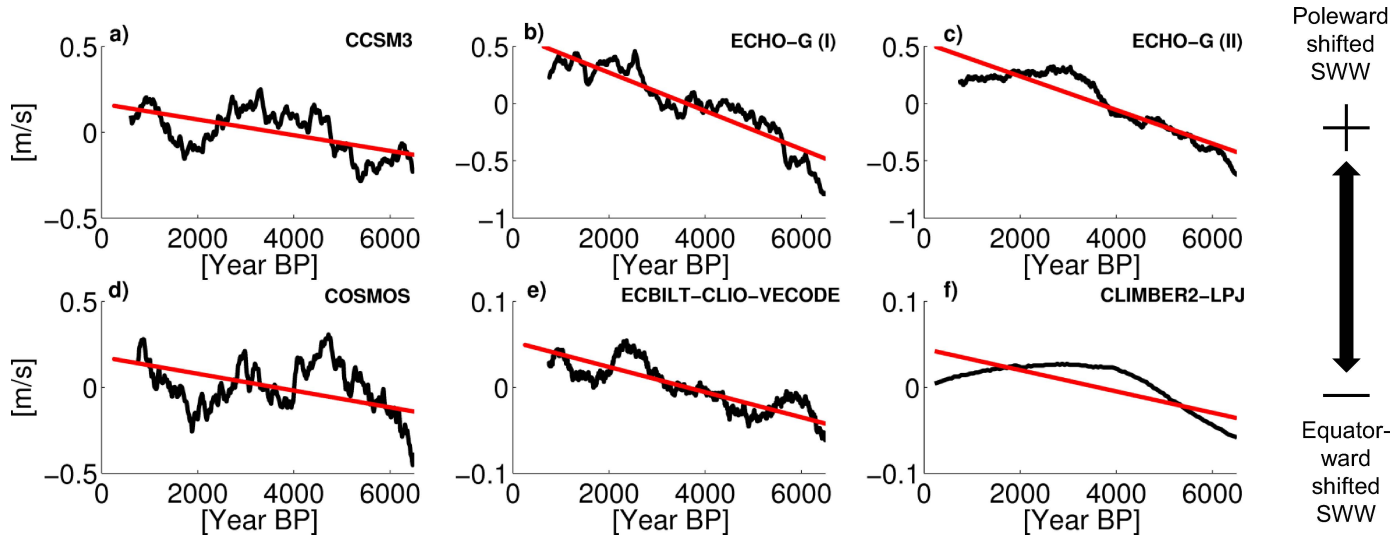

Fig. 4. Temporal evolution of annual-mean SWW position during the period $7 \mathrm{kyr}$ BP to $250 \mathrm{yr}$ BP in (a) CCSM3, (b) ECHO-G (I), (c) ECHO-G (II), (d) COSMOS, (e) ECBilt-CLIO-VECODE, and (f) CLIMBER2-LPJ, defined in terms of the difference between the latitudes $55^{\circ} \mathrm{S}$ and $35^{\circ} \mathrm{S}$ (southern and northern parts of the SWW belt respectively) of the zonally averaged low-level zonal winds (black curves). The time axis is plotted against the anomaly of the mean wind position. A $1000 \mathrm{yr}$ boxcar smoothing with respect to the orbital year has been applied to all the time series except for CLIMBER2-LPJ. Linear regression lines for the unsmoothed time series are shown in red. Note the different ordinate scales.
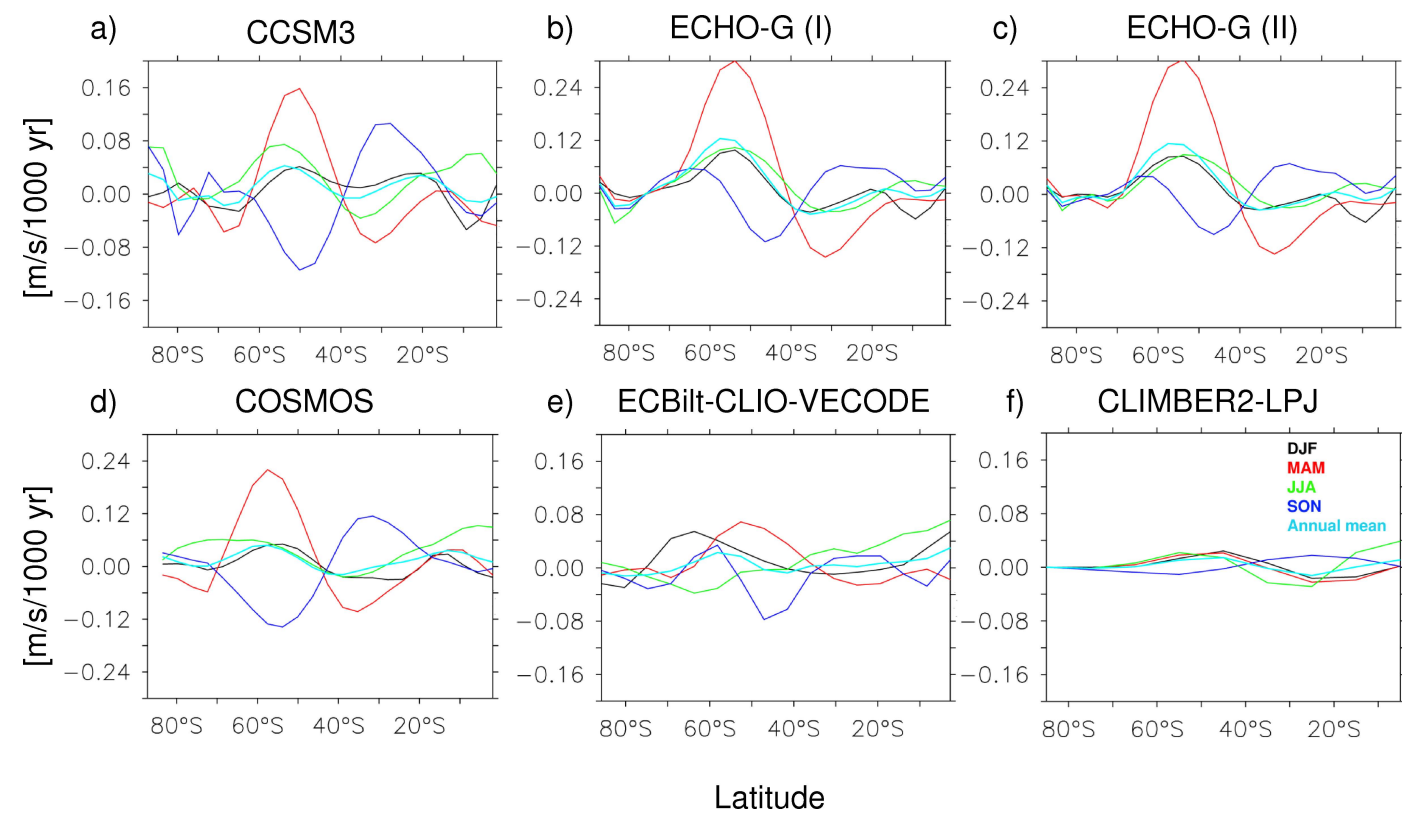

Fig. 5. Zonally averaged seasonal and annual mean trends in the low-level zonal wind in (a) CCSM3, (b) ECHO-G (I), (c) ECHO-G (II), (d) COSMOS, (e) ECBilt-CLIO-VECODE, and (d) CLIMBER2-LPJ for the Southern Hemisphere for the period $7 \mathrm{kyr}$ BP to $250 \mathrm{yr}$ BP. Note the different ordinate scales.

\subsection{Annual and seasonal mean trends in surface tem- perature}

The spatial distributions of Holocene trends in the Southern Hemisphere annual-mean surface temperature for the period $7 \mathrm{kyr}$ BP to $250 \mathrm{yr}$ BP is shown in Fig. 6. The most noticeable trend pattern in all models relates to an intense cooling in the southern high latitudes especially around Antarctica. In low latitudes, the temperature trend patterns are more heterogeneous among the different models. For instance, CCSM3 exhibits a large-scale (albeit weak) tropical warming trend, while ECHO-G (II) shows more of a tropical cooling (Fig. 6c).

The seasonal response pattern of Holocene surface temperature trends in the Southern Hemisphere caused by variations in orbital forcing is more entangled. The zonally averaged trends in the surface temperature on a seasonal basis as simulated by the different models are displayed in Fig. 7 
a)
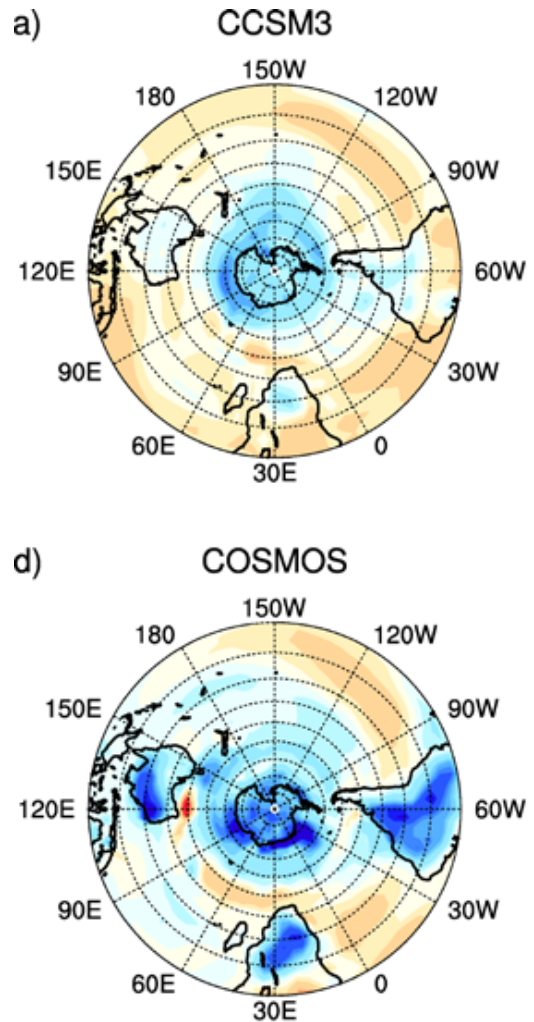

b)

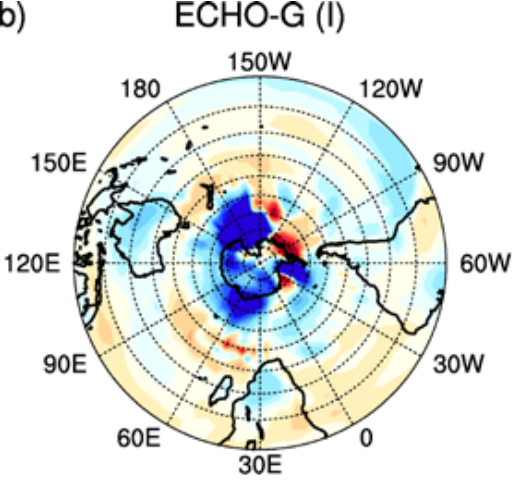

e)

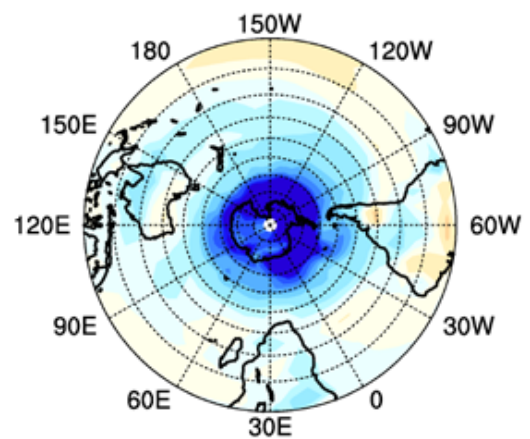

c)

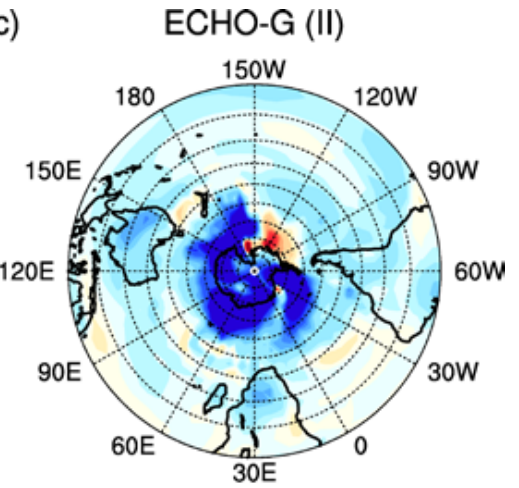

f)

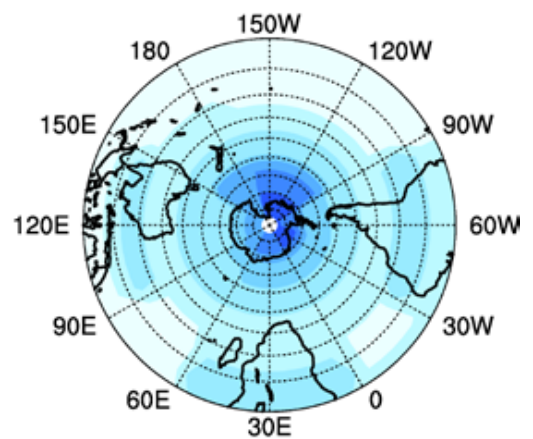

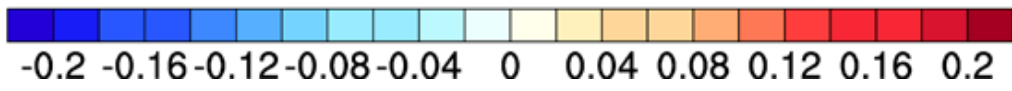

$[\mathrm{K} / 1000 \mathrm{yr}]$

Fig. 6. Trend in the annual-mean surface temperature in (a) CCSM3, (b) ECHO-G (I), (c) ECHO-G (II), (d) COSMOS, (e) ECBilt-CLIOVECODE, and (f) CLIMBER2-LPJ for the period $7 \mathrm{kyr}$ BP to $250 \mathrm{yr}$ BP.

(see Figs. 6-9 of the Supplement for the Southern Hemisphere maps of seasonal trends in surface temperature). Austral summers (DJF) experience a lower-than-present insolation during the early Holocene (Fig. 2) resulting in a general warming trend in the Southern Hemisphere during the course of the Holocene, which is most pronounced over the continents (Fig. 8 in the Supplement). By contrast, the austral winter season (JJA) shows strong cooling trends over the Southern Hemisphere continents as a direct response to decreasing insolation (Fig. 6 in the Supplement). The MAM and SON seasons exhibit the most uniform trends on a hemispherical scale over both Southern Hemisphere land and ocean in all the models (Figs. 5 and 7 in the Supplement). Among all the seasons, the austral spring (SON) shows the strongest seasonal cooling trend, whereas the austral fall (MAM) exhibits the strongest seasonal warming trend (Fig. 7) as a result of insolation changes in combination with a delayed response of the climate system by 1-3 months owing to the thermal inertia of the surface ocean (cf. Renssen et al., 2005). However, even during the MAM season, the Southern Ocean regions around Antarctica show a cooling trend, opposite to what would be expected from the local in- solation trend (Fig. 2). This regional cooling trend has been attributed to the long memory of the Southern Ocean through the storage of late winter-spring surface temperature anomalies in the deep upper-ocean winter layer in combination with sea ice-albedo and ice-insulation feedbacks (Renssen et al., 2005). While the study of Renssen et al. (2005) is based on a single coupled model, our multi-model inter-comparison supports their results and reveals that this is a robust feature captured by all models. As a result, all models show a year-round Holocene cooling trend in the Southern Ocean (Figs. 6, 7).

\section{Discussion}

The Southern Hemisphere surface westerlies mainly result from the convergence of transient eddy momentum fluxes acting against losses by surface friction. The eddies, in turn, are driven by the potential energy available from tropospheric temperature gradients (e.g. Lorenz, 1955; Lindzen and Farrell, 1980) that are ultimately caused by the meridional gradient in incoming solar radiation. Almost $70 \%$ of the shortwave radiation that enters the atmosphere and is not 

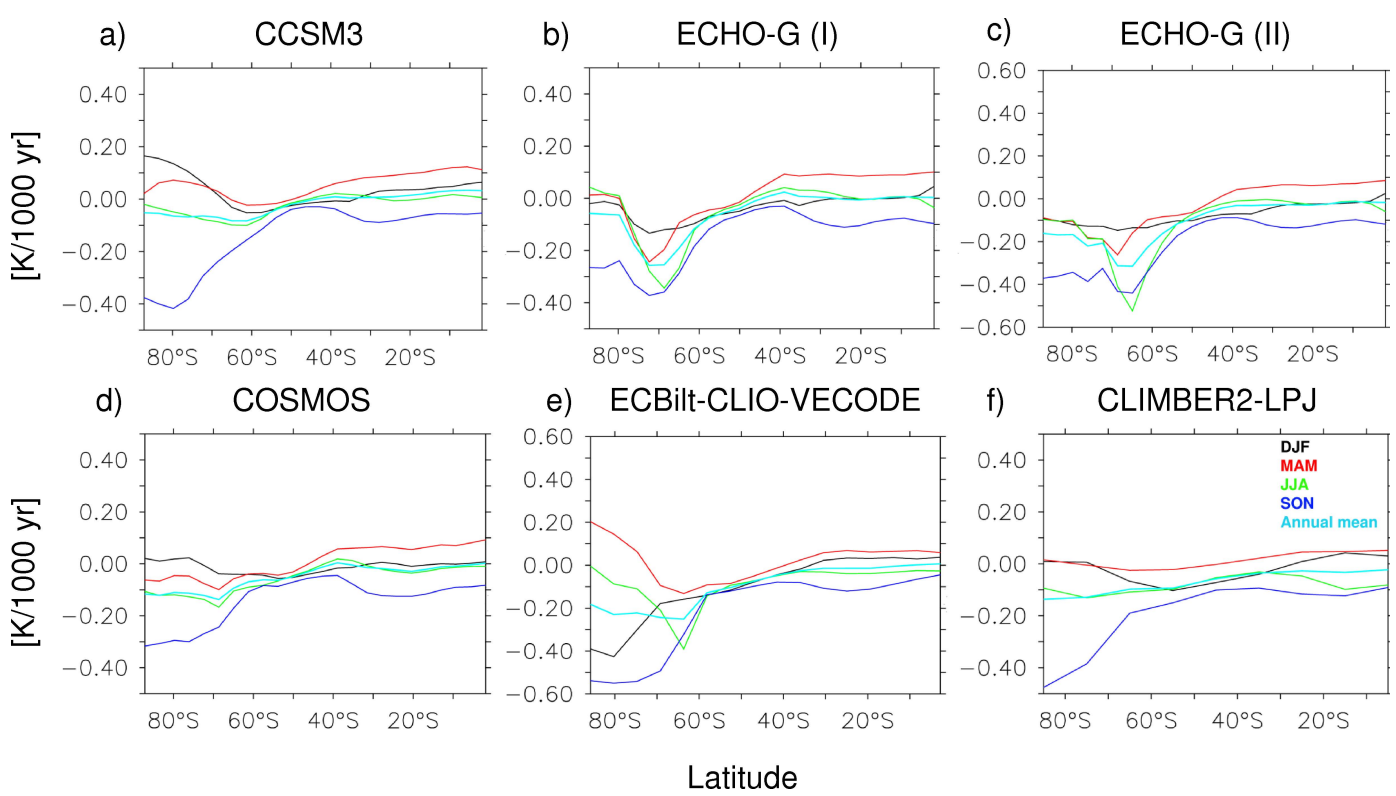

Fig. 7. Zonally averaged seasonal and annual mean trends in the surface temperature in (a) CCSM3, (b) ECHO-G (I), (c) ECHO-G (II), (d) COSMOS, (e) ECBilt-CLIO-VECODE, and (d) CLIMBER2-LPJ for the Southern Hemisphere for the period $7 \mathrm{kyr}$ BP to $250 \mathrm{yr}$ BP. Note the different ordinate scales.

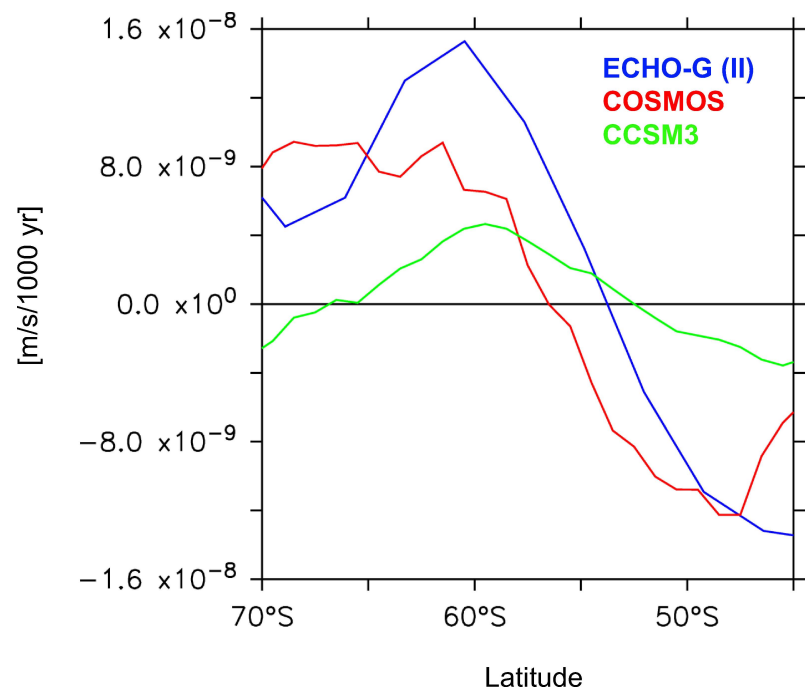

Fig. 8. Zonally averaged annual-mean trends in the Southern Ocean upwelling (based on ocean vertical velocity at $30 \mathrm{~m}$ depth) for ECHO-G (II) (blue), COSMOS (red) and CCSM3 (green) for the period $7 \mathrm{kyr}$ BP to $250 \mathrm{yr}$ BP. Positive trends indicate strengthening of upwelling.

reflected back to space is absorbed at the surface (e.g. Kiehl and Trenberth, 1997). Varying insolation has therefore a direct effect on SST which, in turn, may influence strength and position of the SWW by affecting baroclinic eddy growth and momentum flux convergence through changes in tropospheric meridional temperature gradients and static stability (Brayshaw et al., 2008; Lu et al., 2010; Chen et al., 2010).
The model results presented in our study consistently suggest that the annual and seasonal mean SWW exhibit an overall strengthening and poleward shifting trend during the course of the mid-to-late Holocene under the influence of orbital forcing, except for the austral spring season (SON), where the SWW exhibit an opposite trend of shifting towards the equator (Fig. 5). During the SON season, the trend in insolation-forcing (Fig. 2) leads to a global SST cooling trend which may explain the equatorward displacement of the midlatitude winds. By means of general atmospheric circulation modelling and scaling arguments, it has recently been shown that a decrease in the global surface temperature reduces the latitudinal extent of the Hadley cell (Frierson et al., 2007) and shifts the eddy-driven westerlies towards the equator $(\mathrm{Lu}$ et al., 2010).

However, the most pronounced surface temperature pattern that could be noted in the annual-mean of the Holocene simulations is the strong cooling trend in the southern high latitudes, especially around Antarctica (Fig. 6). Ice cores indeed provide evidence for a widespread Antarctic Holocene cooling trend (Masson et al., 2000) underpinned by palaeoclimate reconstructions from the Ross Sea (Steig et al., 1998) and the Palmer Deep (Domack et al., 2001). The southern high-latitude cooling trend results in a steepening of the pole-to-equator surface temperature gradient. Theoretical and modelling studies have shown that an enhanced meridional surface temperature gradient affects the position of the westerlies (Brayshaw et al., 2008; Lu et al., 2010; Chen et al., 2010). An increasing meridional SST gradient - especially in the mid-latitudes between $40^{\circ}$ and $50^{\circ} \mathrm{S}$ - results in a poleward shift of the eddy-driven zonal winds (Chen et 
al., 2010). This may explain the overall poleward shifting trend of the SWW that prevails in the annual-mean in all the models. During the MAM season, increasing insolation during the austral late summer with highest values in low latitudes (i.e. increasing meridional insolation gradient; Fig. 2) in combination with the 1-3 months time lag, owing to the thermal inertia of the surface climate system (e.g. Renssen et al., 2005) leads to a further increase in the meridional temperature gradient (in particular in the mid-latitudes between $40^{\circ}$ and $50^{\circ} \mathrm{S}$; Fig. 7) as well as to a global SST warming trend. Therefore, the poleward shifting trend of the SWW is strongest during the austral fall.

Our findings for a poleward shift of SWW from the earlymid Holocene to the present are largely consistent with a recent study by Rojas and Moreno (2010), who analyzed a multi-model-mean of PMIP2 simulations for $6 \mathrm{kyr}$ BP. They found an enhanced annual-mean westerly flow between $\sim 35^{\circ} \mathrm{S}$ and $45^{\circ} \mathrm{S}$ and a weakening south of $\sim 45^{\circ} \mathrm{S}$ for the mid-Holocene time slice relative to the present.

In order to assess the influence of the simulated Holocene SWW trends on Southern Ocean upwelling, we analyzed the trends in annual-mean upper-ocean vertical velocity in the comprehensive climate models (the EMICs were not considered here because of their relatively weak SWW trends). Figure 8 shows that the annual-mean poleward shifting SWW trend in all the models is accompanied by a positive trend in upwelling south of $\sim 55^{\circ} \mathrm{S}$. Whether the simulated trends in Southern Ocean upwelling had the potential to significantly affect atmospheric $\mathrm{CO}_{2}$ concentrations through degassing of the deep ocean (cf. Moreno et al., 2010) remains unclear without implementation of carbon cycle models. We further note that the degree of realism to which non-eddy resolving ocean models simulate the upwelling response to SWW changes is under debate (e.g. Böning et al., 2008; Meredith et al., 2012).

Validating the model results with reconstructions of the paleo-SWW proves still to be elusive, as there is a substantial incongruity between different proxy records. For the SWW core region around $51^{\circ}-53^{\circ} \mathrm{S}$, for instance, terrestrial ecosystem proxy records from western Patagonia (Moreno et al., 2010) suggest a trend of increasing SWW strength during the past $7000 \mathrm{yr}$ that is not supported by sedimentological and pollen-based reconstructions of South Patagonian precipitation by Lamy et al. (2010). As a cautionary note, we emphasize again that the model simulations suggest opposite Holocene trends in SWW strength and position for different seasons (Fig. 5) which may affect the proxy records and their interpretation.

In view of a substantial incongruity between different SWW simulations for the Last Glacial Maximum (Rojas et al., 2009), the agreement among the different models with respect to Holocene SWW trends is encouraging. One reason for this outcome may be the relatively simple forcing (insolation only) in the Holocene experiments, whereas the forcing for the Last Glacial Maximum simulations addition- ally includes atmospheric greenhouse gases and continental ice-sheets with potentially opposing effects on the SWW via tropospheric and middle atmosphere temperatures and temperature gradients, static stability, tropopause height, ocean circulation, etc. (e.g. Shindell and Schmidt, 2004; Lorenz and deWeaver, 2007; Toggweiler and Russell, 2008; Lu et al., 2010; Lee et al., 2011).

\section{Conclusions}

The investigation of the temporal and spatial evolution of the SWW along with forcings and feedbacks remains a significant challenge in climate research. In this study, we examined the Holocene evolution of SWW under the influence of orbital forcing with transient experiments using the state-of-the-art comprehensive coupled global climate model CCSM3. In addition, a model inter-comparison has been conducted using Holocene transient simulations from four other coupled global climate models, namely, ECHO-G, COSMOS, ECBilt-CLIO-VECODE and CLIMBER2-LPJ. Analyses and comparison of the model results suggest that the annual and seasonal mean SWW were subject to an overall strengthening and poleward shift during the course of the mid-to-late Holocene under the influence of orbital forcing, except for the austral spring season, where the SWW exhibited an opposite trend of shifting towards the equator. The magnitude of the SWW shift is much smaller in the EMICs compared to the comprehensive general circulation models such that the potential feedbacks in their climate/carbon cycle simulations may be underestimated. The comparison between an accelerated and a non-accelerated ECHO-G experiment revealed that the simulation of the analyzed trends is unaffected by the orbital acceleration technique employed in some of the transient runs.

Whether the simulated shifts in the SWW had the potential to significantly affect Holocene atmospheric $\mathrm{CO}_{2}$ concentrations through degassing of the deep ocean via changes in wind-driven upwelling in the Southern Ocean (Moreno et al., 2010) remains elusive for the time being. Moreover, the effect of increasing greenhouse gases from the mid to the late Holocene (e.g. Raynaud et al., 2000) is not included in the orbital-forced model simulations presented here, although there is strong evidence for a $\mathrm{CO}_{2}$-induced strengthening and poleward shift of the SWW over the past four decades (e.g. Arblaster and Meehl, 2006; Toggweiler and Russell, 2008). In future studies, the combined effects of orbital and greenhouse gas forcing should be explored using comprehensive climate models in order to put the Southern Hemisphere circulation changes of the last decades into a long-term context. 
Supplementary material related to this article is available online at: http://www.clim-past.net/8/391/2012/ cp-8-391-2012-supplement.pdf.

Acknowledgements. We would like to thank the two anonymous reviewers for their constructive comments and suggestions. This work was funded through the DFG (Deutsche Forschungsgemeinschaft) Priority Programme "INTERDYNAMIK" and through the DFG Research Center/Excellence Cluster "The Ocean in the Earth System". CCSM3 simulations were performed on the SGI Altix supercomputer of the Norddeutscher Verbund für Hoch- und Höchstleistungsrechnen (HLRN). We also acknowledge the use of the NCAR Command Language (NCL) and NOAA/PMEL's Ferret in our data analysis and visualization herein.

Edited by: M. Siddall

\section{References}

Anderson, R. F., Ali, S., Bradtmiller, L. I., Nielsen, S. H. H., Fleisher, M. Q., Anderson, B. E., and Burckle, L. H.: Wind-Driven Upwelling in the Southern Ocean and the Deglacial Rise in Atmospheric $\mathrm{CO}_{2}$, Science, 323, 1443-1448, doi:10.1126/science.1167441, 2009.

Arblaster, J. M. and Meehl, G. A.: Contributions of External Forcings to Southern Annular Mode Trends, J. Climate, 19, 28962905, doi:10.1175/JCLI3774.1, 2006.

Archer, D.: A data-driven model of the global calcite lysocline, Global Biogeochem. Cy., 10, 511-526, doi:10.1029/96GB01521, 1996.

Battarbee, R. W. and Binney, H. A.: Natural Climate Variability and Global Warming: A Holocene Perspective, Wiley-Blackwell, ISBN:978-1-4051-5905-0, 2008.

Berger, A. L.: Long-term variations of daily insolation and Quaternary climatic changes, J. Atmos. Sci., 35, 2362-2367, doi:10.1175/1520-0469(1978)035<2362:LTVODI > 2.0.CO;2, 1978.

Biastoch, A., Böning, C. W., Schwarzkopf, F. U., and Lutjeharms, J. R. E.: Increase in Agulhas leakage due to poleward shift of Southern Hemisphere westerlies, Nature, 462, 495-498, doi:10.1038/nature08519, 2009.

Böning, C. W., Dispert, A., Visbeck, M., Rintoul, S. R., and Schwarzkopf, F. U.: The response of the Antarctic Circumpolar Current to recent climate change, Nat. Geosci., 864-869, doi:10.1038/ngeo362, 2008.

Braconnot, P., Otto-Bliesner, B., Harrison, S., Joussaume, S., Peterchmitt, J.-Y., Abe-Ouchi, A., Crucifix, M., Driesschaert, E., Fichefet, Th., Hewitt, C. D., Kageyama, M., Kitoh, A., Laîné, A., Loutre, M.-F., Marti, O., Merkel, U., Ramstein, G., Valdes, P., Weber, S. L., Yu, Y., and Zhao, Y.: Results of PMIP2 coupled simulations of the Mid-Holocene and Last Glacial Maximum Part 1: experiments and large-scale features, Clim. Past, 3, 261277, doi:10.5194/cp-3-261-2007, 2007.

Brayshaw, D. J., Hoskins, B., and Blackburn, M.: The Storm-Track Response to Idealized SST Perturbations in an Aquaplanet GCM, J. Atmos. Sci., 65, 2842-2860, doi:10.1175/2008JAS2657.1, 2008.
Brovkin, V., Bendtsen, J., Claussen, M., Ganopolski, A., Kubatzki, C., Petoukhov, V., and Andreev, A.: Carbon cycle, vegetation, and climate dynamics in the Holocene: Experiments with the CLIMBER-2 model, Global Biogeochem. Cy., 16, 1139, doi:10.1029/2001GB001662, 2002.

Brovkin, V., Ganopolski, A., Archer, D., and Rahmstorf, S.: Lowering of glacial atmospheric $\mathrm{CO}_{2}$ in response to changes in oceanic circulation and marine biogeochemistry, Paleoceanography, 22, PA4202, doi:10.1029/2006PA001380, 2007.

Brovkin, V., Raddatz, T., Christian, H., Reick, C. H., Claussen, M., and Gayler, V.: Global biogeophysical interactions between forest and climate, Geophys. Res. Lett., 36, L07405, doi:10.1029/2009GL037543, 2009.

Chen, G., Plumb, R. A., and Lu, J.: Sensitivities of zonal mean atmospheric circulation to SST warming in an aqua-planet model, Geophys. Res. Lett., 37, L12701, doi:10.1029/2010GL043473, 2010.

Collins, W. D., Bitz, C. M., Blackmon, M. L., Bonan, G. B., Bretherton, C. S., Carton, J. A., Chang, P., Doney, S. C., Hack, J. J., Henderson, T. B., Kiehl, J. T., Large, W. G., McKenna, D. S., Santer, B. D., and Smith, R. D.: The Community Climate System Model Version 3 (CCSM3), J. Climate, 19, 2122-2143, doi:10.1175/JCLI3761.1, 2006.

Domack, E. W., Leventer, A., Dunbar, R., Taylor,F., Brachfeld, S., Sjunneskog, C., and ODP Leg 178 Scientific Party: Chronology of the Palmer Deep site, Antarctic Peninsula: a Holocene palaeoenvironmental reference for the circum-Antarctic, The Holocene, 11, 1-9, doi:10.1191/095968301673881493, 2001.

Frierson, D. M. W., Lu, J., and Chen, G.: Width of the Hadley cell in simple and comprehensive general circulation models, Geophys. Res. Lett., 34, L18804, doi:10.1029/2007GL031115, 2007.

Goosse, H. and Fichefet, T.: Importance of ice-ocean interactions for the global ocean circulation: a model study, J. Geophys. Res., 104, 23337-23355, doi:10.1029/1999JC900215, 1999.

Grootes, P. M. and Stuiver, M.: Oxygen 18/16 variability in Greenland snow and ice with $10^{-3}$ - to $10^{5}$-year time resolution, J. Geophys. Res., 102, 26455-26470, 1997.

Hays, J. D., Imbrie, J., and Shackleton, N. J.: Variations in the earth's orbit: Pacemaker of the ice ages, Science, 194, 11211132, doi:10.1126/science.194.4270.1121, 1976.

Heusser, C. J.: Polar perspective of Late Quaternary climates in the Southern Hemisphere, Quaternary Res., 32, 60-71, doi:10.1016/0033-5894(89)90032-X, 1989.

Imbrie, J., Boyle, E. A., Clemens, S. C., Duffy, A., Howard, W. R., Kukla, G., Kutzbach, J., Martinson, D. J., McIntyre, J., Mix, A. C., Molfino, B., Morley, J. J., Peterson, L. C., Pisias, N. G., Prell, W. L., Raymo, M. E., Shackleton, N. J., and Toggweiler, J. R.: On the Structure and Origin of Major Glaciation Cycles 1. Linear Responses to Milankovitch Forcing, Paleoceanography, 7, 701-738, doi:10.1029/92PA02253, 1992.

Jenny, B., Wilhelm, D., and Valero-Garcés, B. L.: The Southern Westerlies in Central Chile: Holocene precipitation estimates based on a water balance model for Laguna Aculeo (33 $\left.50^{\prime} \mathrm{S}\right)$, Clim. Dynam., 20, 269-280, doi:10.1007/s00382-002-0267-3, 2003.

Kalnay, E., Kanamitsu, M., Kistler, R., Collins, W., Deaven, D., Gandin, L., Iredell, M., Saha, S., White, G., Woollen, J., Zhu, Y., Leetmaa, A., Reynolds, R., Chelliah, M., Ebisuzaki, W., Higgins, W., Janowiak, J., Mo, K. C., Ropelewski, C., Wang, J., 
Jenne, R., and Joseph, D.: The NCEP/NCAR 40-Year Reanalysis Project, B. Am. Meteorol. Soc., 77, 437-471, doi:10.1175/15200477(1996)077<0437:TNYRP>2.0.CO;2, 1996.

Kiehl, J. T. and Trenberth, K. E.: Earth's annual global mean energy budget, B. Am. Meteorol. Soc., 78, 197-208, 1997.

Kim, S. -J., Flato, G. M., and Boer, G. J.: A coupled climate simulation of the last glacial maximum, Part 2: approach to equilibrium, Clim. Dynam., 20, 635-661, doi:10.1007/s00382-0020292-2, 2003.

Kitoh, A., Murakami, S., and Koide, H.: A simulation of the last glacial maximum with a coupled atmosphere-ocean GCM, Geophys. Res. Lett., 28, 2221-2224, doi:10.1029/2000GL012271, 2001.

Kleinen, T., Brovkin, V., von Bloh, W., Archer, D., and Munhoven, G.: Holocene carbon cycle dynamics, Geophys. Res. Lett., 37, L02705, doi:10.1029/2009GL041391, 2010.

Kuhlbrodt, T., Griesel, A., Montoya, M., Levermann, A., Hofmann, M., and Rahmstorf, F.: On the driving processes of the Atlantic meridional overturning circulation, Rev. Geophys., 45, RG2001, doi:10.1029/2004RG000166, 2007.

Lamy, F., Hebbeln, D., and Wefer, G.: Late quaternary precessional cycles of terrigenous sediment input off the Norte Chico, Chile $\left(27.5^{\circ} \mathrm{S}\right)$ and palaeoclimatic implications, Palaeogeogr. Palaeoecol., 140, 233-244, doi:10.1016/S0031-0182(98)900529, 1998.

Lamy, F., Hebbeln, D., and Wefer, G.: High-resolution marine record of climatic change in mid-latitude Chile during the last 28,000 years based on terrigenous sediment parameters, Quaternary Res., 51, 83-93, doi:10.1006/qres.1998.2010, 1999.

Lamy, F., Hebbeln, D., Rohl, U., and Wefer, G.: Holocene rainfall variability in southern Chile: a marine record of latitudinal shifts of the Southern Westerlies, Earth Planet. Sc. Lett., 185, 369-382, doi:10.1016/S0012-821X(00)00381-2, 2001.

Lamy, F., Kilian, R., Arz, H. W., Francois, J. P., Kaiser, J., Prange, M., and Steinke, T.: Holocene changes in the position and intensity of the southern westerly wind belt, Nat. Geosci., 3, 695-699, doi:10.1038/ngeo959, 2010.

Lee, S.-Y., Chiang, J. C. H., Matsumoto, K., and Tokos, K. S.: Southern Ocean wind response to North Atlantic cooling and the rise in atmospheric $\mathrm{CO}_{2}$ : Modeling perspective and paleoceanographic implications, Paleoceanography, 26, PA1214, doi:10.1029/2010PA002004, 2011.

Legutke, S. and Voss, R.: The Hamburg atmosphere-ocean coupled circulation model ECHO-G, Technical Report 18, Deutsches Klimarechenzentrum, Hamburg, 1999.

Levitus, S., Boyer, T. P., Conkright, M. E., O’Brien, T., Antonov, J., Stephens, C., Stathoplos, L., Johnson, D., and Gelfeld, R.: Introduction. Vol. 1, World Ocean Database 1998, NOAA Atlas NESDIS 18, US Gov. Printing Office, Wash., D.C., 346 pp., 1998.

Lindzen, R. S. and Farrell, B.: A simple approximation result for maximum growth rate of baroclinic instabilities, J. Atmos. Sci., 37, 1648-1654, doi:10.1175/15200469(1980)037<1648:ASARFT > 2.0.CO;2, 1980.

Lorenz, D. J. and DeWeaver, E. T.: Tropopause height and zonal wind response to global warming in the IPCC scenario integrations, J. Geophys. Res., 112, D10119, doi:10.1029/2006JD008087, 2007.

Lorenz, E. N.: Available potential energy and the maintenance of the general circulation, Tellus, 7, 157-167, doi: 10.1111/j.21533490.1955.tb01148.x, 1955.

Lorenz, S. J. and Lohmann, G.: Acceleration technique for Milankovitch type forcing in a coupled atmosphere-ocean circulation model: method and application for the Holocene, Clim. Dynam., 23, 727-743, doi:10.1007/s00382-004-0469-y, 2004.

Lorenz, S. J., Kim, J.-H., Rimbu, N., Schneider, R. R., and Lohmann, G.: Orbitally driven insolation forcing on Holocene climate trends: Evidence from alkenone data and climate modeling, Paleoceanography, 21, PA1002, doi:10.1029/2005PA001152, 2006.

Lu, J., Chen, G., and Frierson, D. M. W.: The Position of Midlatitude Storm Track and Eddy-Driven Westerlies in Aquaplanet AGCMs, J. Atmos. Sci., 67, 3984-4000, doi:10.1175/2010JAS3477.1, 2010.

Markgraf, V.: Paleoenvironmental changes at the northern limit of the subantarctic Nothofagus forest, Lat $37^{\circ} \mathrm{S}$, Quaternary Res., 28, 119-129, 1987.

Markgraf, V., Dodson, J. R., Kershaw, A. P., McGlone, M. S., and Nicholls, N.: Evolution of late Pleistocene and Holocene climates in the circum-South Pacific land areas, Clim. Dynam., 6, 193-211, doi:10.1007/BF00193532, 1992.

Marsland, S. J., Haak, H., Jungclaus, J. H., Latif, M., and Röske, F.: The Max-Planck-Institute global ocean/sea ice model with orthogonal curvilinear coordinates, Ocean Modell., 5, 91-127, 2003.

Masson, V., Vimeux, F., Jouzel, J., Morgan, V., Delmotte, M., Ciais, P., Hammer, C., Johnsen, S., Lipenkov, V,Ya., Thompson, M.E., Petit, J, R., Steig, E. J., Stievenard, M., and Vaikmae, R.: Holocene Climate variability in Antarctica Based on 11 Ice-Core Isotopic Records, Quaternary Res., 54, 348-358, doi:10.1006/qres.2000.2172, 2000.

Menviel, L., Timmermann, A., Mouchet, A., and Timm, O.: Climate and marine carbon cycle response to changes in the strength of the Southern Hemispheric westerlies, Paleoceanography, 23, PA4201, doi:10.1029/2008PA001604, 2008.

Meredith, M. P., Garabato, A. C. N., Hogg, A. M., and Farneti, R.: Sensitivity of the Overturning Circulation in the Southern Ocean to Decadal Changes in Wind Forcing, J. Climate, 25, 99-110, doi:10.1175/2011JCLI4204.1, 2012.

Merkel, U., Prange, M., and Schulz, M.: ENSO variability and teleconnections during glacial climates, Quaternary Sci. Rev., 29, 86-100, doi:10.1016/j.quascirev.2009.11.006, 2010.

Milankovitch, M.: Kanon der Erdbestrahlungen und seine Anwendung auf das Eiszeitenproblem, Spec Publ, R. Serb. Acad., Belgrade, 132, 633 pp., 1941.

Moreno, P. I., Francois, J. P., Moy, C. M., and Villa-Martinez, R.: Covariability of the Southern Westerlies and atmospheric $\mathrm{CO}_{2}$ during the Holocene, Geology, 38, 727-730, doi:10.1130/G30962.1, 2010.

Opsteegh, J. D., Haarsma, R. J., Selten, F. M., and Kattenberg, A.: ECBILT: A dynamic alternative to mixed boundary conditions in ocean models, Tellus, 50A, 348-367, doi:10.1034/j.16000870.1998.t01-1-00007.x, 1998.

d'Orgeville, M., Sijp, W. P., England, M. H., and Meissner, K. J.: On the control of glacial-interglacial atmospheric $\mathrm{CO}_{2}$ variations by the Southern Hemisphere Westerlies, Geophys. Res. Lett., 37, L21703, doi:10.1029/2010GL045261, 2010.

Otto-Bliesner, B., Brady, E., Clauzet, G., Thomas, R., Levis, S., 
and Kothavala, Z.: Last glacial maximum and Holocene climate in CCSM3, J. Climate, 19, 2526-2544, doi:10.1175/JCLI3748.1, 2006.

Petoukhov, V., Ganopolski, A., Brovkin, V., Claussen, M., Eliseev, A., Kubatzki, C and Rahmstorf, S.: CLIMBER-2: A climate system model of intermediate complexity. Part I: Model description and performance for present climate, Clim. Dynam., 16, 1-17, doi:10.1007/PL00007919, 2000.

Raynaud, D., Barnola, J-M., Chappellaz, J., Blunier, T., Indermühle, A., and Stauffer, B.: The ice record of green house gases: a view in the context of future changes, Quaternary Sci. Rev., 19, 9-17, doi:10.1016/S0277-3791(99)00082-7, 2000.

Renssen, H., Goosse, H., Fichefet, T., Masson, V., and Koc, N.: Holocene climate evolution in the high-latitude Southern Hemisphere simulated by a coupled atmospheresea-ice-ocean-vegetation model, The Holocene, 15, 951-964, doi:10.1191/0959683605hl869ra, 2005.

Renssen, H., Seppä, H., Heiri, O., Roche, D. M., Goosse, H., and Fichefet, T.: The spatial and temporal complexity of the Holocene thermal maximum, Nat. Geosci., 2, 411-414, doi:10.1038/ngeo513, 2009.

Roeckner, E., Arpe, K., Bengtsson, L., Christoph, M., Claussen, M., Dümenil, L., Esch, M., Giorgetta, M., Schlese, U., and Schulzweida, U.: The atmospheric general circulation model ECHAM-4: model description and simulation of the present day climate, Max-Planck-Institut fur Meteorologie Rep. 218, 1996.

Roeckner, E., Bäuml, G., Bonaventura, L., Brokopf, R., Esch, M., Giorgetta, M., Hagemann, S., Kirchner, I., Kornblueh, L., Manzini, E., Rhodin, A., Schlese, U., Schulzweida, U., and Tompkins, A.: The atmospheric general circulation model ECHAM5. Part I: Model description, Max Planck Institute for Meteorology Rep. 349, 2003.

Rojas, M. and Moreno, P. I.: Atmospheric circulation changes and neoglacial conditions in the Southern Hemisphere mid-latitudes: insights from PMIP2 simulations at $6 \mathrm{kyr}$, Clim. Dynam., 37, 357-375, doi:10.1007/s00382-010-0866-3, 2010.

Rojas, M., Moreno, P., Kageyama, M., Crucifix, M., Hewitt, C., Abe-Ouchi, A., Ohgaito, R., Brady, E. C., and Hope, P.: The Southern Westerlies during the last glacial maximum in PMIP2 simulations, Clim. Dynam., 32, 525-548, doi:10.1007/s00382008-0421-7, 2009.

Sen Gupta, A. and England, M. H.: Coupled Ocean-AtmosphereIce Response to Variations in the Southern Annular Mode, J. Climate, 19, 4457-4486, doi:10.1175/JCLI3843.1, 2006.

Shin, S. I., Lui, Z., Otto-Bliesner, B., Brady, E. C., Kutzbach, J. E., and Harrison, S. P.: A simulation of the last glacial maximum climate using NCAR CCSM, Clim. Dynam., 20, 127-151, doi:10.1007/s00382-002-0260-x, 2003.

Shindell, D. T. and Schmidt, G. A.: Southern Hemisphere climate response to ozone changes and greenhouse gas increases, Geophys. Res. Lett., 31, L18209, doi:10.1029/2004GL020724, 2004.

Shulmeister, J., Goodwin, I., Renwick, J., Harle, K., Armand, L., McGlone, M. S., Cook, E., Dodson, J., Hesse, P. P., Mayewski, P., and Curran, M.: The Southern Hemisphere westerlies in the Australasian sector over the last glacial cycle: a synthesis, Quatern. Int., 118-119, 23-53, 2004.
Sijp, W. P. and England, M. H.: Southern Hemisphere Westerly Wind Control over the Ocean's Thermohaline Circulation, J. Climate, 22, 1277-1286, doi:10.1175/2008JCLI2310.1, 2009.

Steig, E. J., Hart, C. P., White, J. W. C., Cunningham, W. L., Davis, M. D., and Saltzman, E. S.: Changes in climate, ocean and icesheet conditions in the Ross embayment, Antarctica, at $6 \mathrm{ka}$, Ann. Glaciol., 27, 305-310, 1998.

Thompson, D. W. J. and Wallace, J. M.: Annular modes in the extratropical circulation. Part I: Month-to-month variability, J. Climate, 13, 1000-1016, doi:10.1175/15200442(2000)013<1000:AMITEC>2.0.CO;2, 2000.

Thresher, R. E.: Solar correlates of Southern Hemisphere midlatitude climate variability, Int. J. Climatol., 22, 901-915, doi:10.1002/joc.768, 2002.

Toggweiler, J. R. and Russell, J.: Ocean circulation in a warming climate, Nature, 451, 286-288, doi:10.1038/nature06590, 2008.

Toggweiler, J. R. and Samuels, B.: Effect of Drake Passage on the global thermohaline circulation, Deep-Sea Res. Pt 1., 42, 477500, doi:10.1016/0967-0637(95)00012-U, 1995.

Toggweiler, J. R., Russel, J. L., and Carson, S. R.: Midlatitude westerlies, atmospheric $\mathrm{CO}_{2}$ and climate change during the ice ages, Paleoceanography, 21, PA2005, doi:10.1029/2005PA001154, 2006.

Tschumi, T., Joos, F., and Parekh, P.: How important are Southern Hemisphere wind changes for low glacial carbon dioxide? A model study, Paleoceanography, 23, PA4208, doi:10.1029/2008PA001592, 2008.

Valdes, P. J.: South American palaeoclimate model simulations: how reliable are the models?, J. Quaternary Sci., 15, 357-368, doi:10.1002/1099-1417(200005)15:4<357::AIDJQS547>3.0.CO;2-8, 2000.

Varma, V., Prange, M., Lamy, F., Merkel, U., and Schulz, M.: Solarforced shifts of the Southern Hemisphere Westerlies during the Holocene, Clim. Past, 7, 339-347, doi:10.5194/cp-7-339-2011, 2011.

Wagner, S., Widmann, M., Jones, J., Haberzettl, T., Lücke, A., Mayr, C., Ohlendorf, C., Schäbitz, F., and Zolitschka, B.: Transient simulations, empirical constructions and forcing mechanisms for the Mid-holocene hydrological climate in southern Patagonia, Clim. Dynam., 29, 333-355, doi:10.1007/s00382007-0229-x, 2007.

Wyroll, K.-H., Dong, B., and Valdes, P.: On the position of southern westerlies at the last glacial maximum: an outline of AGCM simulation results and evaluation of their implications, Quaternary Sci. Rev., 19, 881-898, doi:10.1016/S0277-3791(99)00047-5, 2000.

Yeager, S. G., Shields, C. A., Larger, W. G., and Hack, J. J.: The low-resolution CCSM3, J. Climate, 19, 2545-2566, doi:10.1175/JCLI3744.1, 2006. 